\title{
IMPLEMENTASI MODEL PEMBELAJARAN GUIDED INQURY PADA MATERI POKOK FLUIDA DINAMIS DI KELAS XI
}

\author{
Pintor Simamora dan Wilvan Manalu \\ Jurusan Fisika FMIPA Universitas Negeri Medan \\ Jalan Willem Iskandar Pasar V Medan, Sumatera Utara \\ pintor_fisika@yahoo.co.id
}

\begin{abstract}
ABSTRAK
Penelitian ini bertujuan untuk mengetahui pengaruh model pembelajaran guided inquiry terhadap hasil belajar siswa pada materi fluida dinamis kelas XI semester II di SMA Negeri 15 Medan Tahun Pelajaran 2015/2016. Jenis penelitian ini adalah quasi experiment. Pengambilan sampel dilakukan dengan cara cluster random sampling dengan mengambil dua kelas dari tujuh kelas, yaitu kelas XI IPA 5 sebagai kelas eksperimen dan kelas XI IPA 3 sebagai kelas kontrol. Instrumen yang digunakan dalam penelitian ini digunakan tes pilihan berganda yang telah divalidkan oleh validator dan observasi aktivitas belajar siswa. Pada pengujian data pretest kedua kelas diperoleh bahwa data kedua kelas berdistribusi normal dan homogen. Setelah pembelajaran selesai, diberikan posttest data posttest kedua kelas berdistribusi normal dan homogen. Berdasarkan hasil uji beda diperoleh bahwa secara signifikan terdapat pengaruh model pembelajaran guided inquiry terhadap hasil belajar siswa pada materi fluida dinamis kelas XI semester II di SMA Negeri 15 Medan.
\end{abstract}

Kata kunci : guided inquiry, hasil belajar, fluida dinamis

\section{PENDAHULUAN}

Pendidikan merupakan proses peningkatan kualitas sumber daya manusia (SDM) yang memiliki peranan dominan dalam kehidupan manusia. Hasil yang ingin dicapai dalam proses pendidikan adalah terbinanya SDM sesuai dengan tuntutan pembangunan, yaitu sosok manusia Indonesia seutuhnya yang bisa memecahkan persoalan hari ini dan masa mendatang. Pendidikan juga merupakan suatu proses pembudayaan nilai-nilai, yang kemudian nilai-nilai tersebut dapat diterapkan dalam bentuk kerja nyata di lapangan. Pada hakekatnya pendidikan adalah suatu usaha penyiapan peserta didik untuk menghadapi lingkungan hidup yang selalu mengalami perubahan yang semakin pesat. Pendidikan merupakan dasar dalam memajukan suatu negara. Majunya suatu negara tercermin dari pendidikan yang maju dan mendapat perhatian secara serius.
Undang-Undang Nomor 20 tahun 2003 tentang sistem pendidikan Nasional menyebutkan, bahwa pendidikan nasional berfungsi mengembangkan kemampuan dan membentuk watak serta perdaban bangsa yang bermartabat dalam rangka mencerdaskan kehidupan bangsa. Tujuan akhir pendidikan itu ialah mendidik anak agar berguna bagi dirinya sendiri serta berguna bagi masyrakat, bangsa dan negaranya.

Proses pendidikan merupakan kegiatan memobilisasi segenap komponen pendidikan oleh pendidik terarah kepada pencapaian tujuan pendidikan. Bagaimana proses pendidikan itu dilaksanakan sangat menentukan kualitas hasil pencapian tujuan pendidikan. Tujuan utama pengelolaan proses pendidikan yaitu terjadinya proses belajar dan pengalaman belajar yang optimal. Pengelolaan proses pendidikan memegang peranan penting. Pengelolaan 
proses pendidikan harus memperhitungkan perkembangan ilmu pengetahuan dan teknologi.

\section{Sani (2014:88:89) menyatakan} bahwa: Pembelajaran berbasis inkuiri adalah pembelajaran yang melibatkan siswa dalam merumuskan pertanyaan yang mengarahkan untuk melakukan investigasi dalam upaya membangun pengetahuan dan makna baru. Inkuiri adalah investigasi tentang ide, pertanyaan, dan permasalahan. Investigasi yang dilakukan dapat berupa kegiatan laboratorium atau aktivitas lainnya yang dapat digunakan untuk mengumpulkan informasi, membangun pengetahuan, dan mengembangkan pemahaman yang mendalam tentang sesuatu yang diselidiki. Selain itu menurut Khulthau, et al., (2012:10). Inkuiri terbimbing adalah cara berpikir, belajar dan mengajar yang mengubah budaya sekolah menjadi sebuah komunitas penyelidikan yang kolaboratif. Inkuiri terbimbing adalah model yang fleksibel yang membantu. Guru untuk memandu siswa melalui alur penemuan dalam proses belajar dari berbagai sumber informasi untuk mempersiapkan siswa berhasil dalam pembelajaran dan hidup di era informasi. Dengan menggunakan model pembelajaran inkuiri diharapkan siswa akan mendapatkan pemahaman-pemahaman yang lebih baik mengenai pelajaran fisika dan akan lebih tertarik dan termotivasi belajar fisika jika siswa dilibatkan secara aktif dalam pembelajaran.

$$
\text { Trianto (2007:135) model }
$$

pembelajaran inkuiri adalah suatu rangkaian kegiatan belajar yang melibatkan secara maksimal seluruh kemampuan siswa untuk mencari dan menyelidiki secara sistematis, kritis , logis, analitis, sehingga mereka dapat merumuskan sendiri penemuannya dengan penuh percaya diri. Model pembelajaran inkuiri merupakan model pembelajaran yang dikembangkan atas dasar teori bahwa secara alami manusia mempunyai kecenderungan untuk selalu mencari tahu akan segala sesuatu yang menarik perhatiannya.
Model inkuiri terbimbing merupakan model pembelajaran yang menekankan kepada pengembangan aspek kognitif, afektif, dan psikomotor secara seimbang, sehingga pembelajaran melalui model ini dianggap lebih bermakna (Sanjaya, 2007:206).

Berkaitan dari uraian di atas dapat disimpulkan bahwa dengan menggunakan model pembelajaran inkuiri terbimbing dapat meningkatkan hasil belajar siswa, sehingga tujuan penelitian ini adalah untuk mengetahui pengaruh model pembelajaran guided inquiry terhadap hasil belajar siswa pada materi fluida dinamis kelas XI semester II di SMA Negeri 15 Medan Tahun Pelajaran 2015/2016.

\section{METODE PENELITIAN}

Penelitian dilaksanakan di SMA Negeri 15 Medan beralamat di Jl. Sekolah pembangunan Sunggal dengan waktu pelaksanaan semester II T.P 2015/2016. Populasi dalam penelitian adalah seluruh siswa kelas XI SMA Negeri 15 Medan yang terdiri dari 7 kelas paralel berjumlah 317 orang pada T.P 2015/2016.

Sampel dalam penelitian terdiri dari dua kelas yaitu kelas kontrol dan kelas eksperimen yang diambil dengan teknik cruster random sampling. Satu kelas dijadikan sebagai kelas eksperimen yaitu kelas XI-IPA 5 yang diajarkan dengan model pembelajaran Guided Inquiry dan satu kelas lagi dijadikan sebagai kelas control yaitu kelas XI-IPA 3 yang diajarkan dengan model pembelajaran langsung. Jenis penelitian ini adalah penelitian quasi eksperimen. Desain dalam penelitian ini menggunakan two group pretest-posttest design seperti ditunjukkan pada Tabel 1.

Tabel 1.Desain Penelitian Two Group Pretest-Post-test Design

\begin{tabular}{|l|c|c|c|}
\hline Kelas & Pretes & Perlakuan & Postes \\
\hline Eksperimen & $\mathrm{T}$ & $\mathrm{P}$ & $\mathrm{T}$ \\
\hline Kontrol & $\mathrm{T}$ & $\mathrm{Q}$ & $\mathrm{T}$ \\
\hline
\end{tabular}

(Arikunto, 2012: 85) 
Keterangan :

$\mathrm{T}=$ Pemberian pretes; $\mathrm{T}=$ Pemberian postes; $\mathrm{P}=$ Perlakuan dengan model pembelajaran Guided Inquiry; $\mathrm{Q}=$ Perlakuan dengan model pembelajaran langsung.

\section{HASIL DAN PEMBAHASAN}

Pada awal penelitian, kedua kelas diberikan tes uji kemampuan awal (pretest) yang bertujuan untuk mengetahui apakah kemampuan awal siswa pada kedua kelas sama atau tidak. Berdasarkan data hasil penelitian pada lampiran diperoleh nilai rata-rata pretest siswa pada kelas eksperimen sebelum diberi perlakuan dengan menggunakan model pembelajaran Guided Inquiry sebesar 43,4 dengan standar deviasi 9,4 dan di kelas kontrol diperoleh nilai rata-rata pretest siswa sebesar 42,3 dengan standar deviasi 8,8.

Untuk melihat secara rinci hasil pretes kedua kelas dapat dilihat pada Gambar 1.

Gambar 1. Hubungan Pretest Kelas Eksperimen dan Kelas Kontrol

Gambar 1 menunjukkan bahwa nilai pretes pada kelas eksperimen dan kelas kontrol tidak jauh berbeda, artinya kedua kelas mempunyai kemampuan awal yang hampir sama dan perolehan nilai kedua kelas merata.

Sebelum dilakukan uji hipotesis terlebih dahulu dilakukan uji prasyarat data yaitu uji normalitas menggunakan uji Lilliefors. Hasil uji normalitas yang diperoleh adalah Kelas Eksperimen $\mathrm{L}_{\text {hitung }}=$ $0,1255, \mathrm{~L}_{\text {tabel }}=0,1497$. Untuk kelas kontrol $\mathrm{L}_{\text {hitung }}=0,1415, \quad \mathrm{~L}_{\text {tabel }}=0,1497$. Kesimpulannya kedua kelas berdistribusi normal.

Pengujian homogenitas dilakukan untuk mengetahui apakah kelas sampel berasal dari populasi yang homogen atau tidak, artinya apakah sampel yang dipakai dalam penelitian ini dapat mewakili seluruh populasi yang ada.
Pengujian homogenitas data dilakukan dengan uji F. Hasil uji homogenitas data yang diperoleh adalah $\mathrm{F}_{\text {hitung }}<\mathrm{F}_{\text {tabel }}=1,12 \square 1,8$. Nilai $\mathrm{F}_{\text {hitung }}<\mathrm{F}$ yang berarti bahwa sampel yang digunakan dalam penelitian ini dinyatakan homogen atau dapat mewakili seluruh populasi yang ada.

Setelah kedua kelas diberikan perlakuan yang berbeda, kedua kelas selanjutnya diberikan posttest dengan soal yang sama seperti soal pretest yang bertujuan untuk mengetahui hasil belajar siswa. Hasil yang diperoleh adalah Berdasarkan data hasil penelitian pada lampiran diperoleh nilai rata-rata posttest siswa pada kelas eksperimen setelah diberi perlakuan dengan menggunakan model pembelajaran Guided Inquiry sebesar 85,3 dengan standar deviasi 7,2 dan di kelas control diperoleh nilai rata-rata posttest siswa sebesar 72,7 dengan standar deviasi 7,2 .

Untuk melihat secara rinci hasil protes kedua kelas dapat dilihat pada Gambar 2.

Gambar 2. Perbandingan Nilai Postest Kelas Eksperimen dan Kelas Kontrol.

Gambar 2 menunjukkan bahwa pada kelas eksperimen, nilai yang dicapai oleh siswa lebih merata dibandingkan pada kelas kontrol. Hal ini menunjukkan bahwa penerapan model pembelajaran Guided inquiry baik untuk dilakukan.

Berdasarkan hasil uji hipotesis diperoleh $t_{\text {hitung }}>t_{\text {tabel }}=7,3>1,66$. Dalam hal ini dapat disimpulkan bahwa hasil belajar siswa pada kelas eksperimen lebih besar dari hasil belajar kelas kontrol, berarti ada pengaruh yang signifikan akibat model pembelajaran Guided Inquiry terhadap hasil belajar pada materi pokok Fluida Dinamis di kelas XI SMA Negeri 15 Medan T.P 2015/2016.

Kuhlthau, et al., (2007:6) menyatakan bahwa pembelajaran inkuiri terbimbing memiliki kelebihan bagi siswa 
yaitu mengembangkan kemampuan sosial, keterampilan berbahasa, membangun pemahaman sendiri mengenai hal yang diselidiki, siswa bebas dalam penyelidikan dan belajar, serta terlibat langsung dalam proses pembelajaran melalui penyelidikan yang dapat dapat meningkatkan hasil belajar siswa.

Hasil penelitian ini sesuai dengan penelitian terdahulu yaitu Puspita dan Jatmiko (2013:123) yang menyatakan bahwa model pembelajaran inkuiri terbimbing dapat membuat siswa belajar lebih aktif untuk memecahkan masalah, membuat hipotesis, melakukan percobaan untuk memperoleh informasi atau data, mengumpulkan dan menganalisis data, dan membuat simpulan.

\section{KESIMPULAN}

Berdasarkan hasil penelitian yang diperoleh dari hasil analisa data dan pengujian hipotesis maka dapat disimpulkan sebagai berikut:

1. Nilai rata-rata hasil belajar siswa pada kelas eksperimen sebelum diberikan perlakuan adalah 43,4 dan setelah diberikan perlakuan dengan model pembelajaran guided inquiry memiliki nilai ratarata sebesar 85,3.

2. Nilai rata-rata hasil belajar siswa pada kelas kontrol sebelum diberikan perlakuan adalah 42,3 dan setelah diberi perlakuan dengan pembelajaran konvensional memiliki nilai ratarata sebesar 72,7.

3. Ada perbedaan dengan menggunakan pembelajaran guided inquiry terhadap hasil belajar siswa pada materi fluida dinamis kelas XI semester II di SMA Negeri 15 Medan Tahun Pelajaran 2015/2016.

\section{DAFTAR PUSTAKA}

Arikunto, S, (2012), Dasar-dasar Evaluasi Pendidikan Edisi 2: Bumi Aksara.

Khulthau, C., Leslie, K.M., \& Ann, K.C., (2012), Guided Inquiry Design: a framework for inquiry in your school. California: libraries unlimited.

Khultau, C. (2007). Guided inquiry. USA: libraries unlimited.Inc

Puspita, A. T. dan Jatmiko, B., (2013), Implementasi Model Pembelajaran Inkuiri Terbimbing (Guided Inquiry) terhadap Keterampilan Berpikir Kritis siswa pada pembelajaran Fisika Materi Fluida Statis Kelas XI di SMA Negeri 2 Sidoarjo, Jurnal Pendidikan Fisika Indonesia 2: 121-125.

Sani, R. A., (2014), Pembelajaran Saintifik untuk Implementasi Kurikulum 2013, Bumi Aksara, Jakarta.

Sanjaya, W. (2008), Pembelajaran Dalam Implementasi Kurikulum Berbasis Kompetensi. Jakarta : Kencana Prenada Media Group.

Trianto, (2007), Mendesaian Model Pembelajaran Inovatif-Progresif. Jakarta : Kencana. 